\title{
İbn Sina ve İhvan-1 Safa Bağlamında Matematikten Metafiziğe Sayı ve Nicelik Algısı
}

\section{Number and Quantity Perception from Mathematical to Metaphysics in the context of Avicenna and Ikbwan al-Safa}

\author{
AYȘE KÖKCÜ \\ Çankırı Karatekin University
}

Received: 03.11.2018 | Accepted: 26.03.2019

\begin{abstract}
The issue of number and quantity is the most fundamental subject of the philosophy of mathematics, which has been discussed for thousands of years and is still not fully defined. In this article, the thoughts of two major schools of philosophy such as the Ikhni-i Safa community and Avicenna (Ibn Sina) on the concepts of number and quantity were examined in Islamic philosophy. The Ikhwan-al-Safa, who was deeply influenced by the Pythagorean doctrine, considered the numbers as the basic principle of everything and the Pythagorean understanding with the Ikhwan became a part of the understanding of Islam. On the other hand, Avicenna who adhered to Aristotle tradition discussed the concepts of continuous and discrete quantity in the context of categories and in the context of the principle of independence of the types.
\end{abstract}

Keywords: Ikhwan al-Safa, Avicenna, number, quantity, philosophy of mathematics, Aristotle, Pythagoras.

(C) Kökcü, A.. (2019). İbn Sina ve İhvan-1 Safa Bağlamında Matematikten Metafiziğe Sayı ve Nicelik Algis1. Beytulbikme An International fournal of Philosophy, 9 (I), 59-74. 


\section{Giriș}

İslâm matematiğinde sayı ve nicelik konusuna girerken ismini anmadan geçemeyeceğimiz șüphesiz ilk isim, Abbasi halifesi Memun (786-933) zamanının seçkin bilim insanlarından olan Ebu Cafer Muhammed bin Harizmi'dir (780-850). Harizmi'nin matematik üzerine yazdığı çok önemli iki eseri bulunmaktadır. Bunlardan birincisi 825 yılında yazılan El-Kitabü'lMubtasar fi Hisab El-Cebr Ve'l-Mukabele adlı eseridir. Adında cebir kelimesinin ilk defa geçtiği bu eser sayesinde, matematiğin çok önemli bir alanı

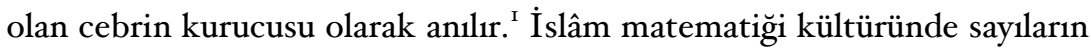
konseptinin anlașllabilmesi için incelenmesi gereken ilk eser, Harizmi'nin cebir kitabıdır. Harizmi eserine sayılarda hane kavramını izah eden bir mukaddimeyle bașlar (Boyer 2015: 26I). Sonrasında tamamen sözel ifadelerden oluşan denklem çözümlerine geçer. Altı tip denklemden bahseden Harizmi’nin denklem tipleri günümüz versiyonuyla:

$$
\begin{array}{ll}
a x^{2}=b x, & a x^{2}+b x=c \\
a x^{2}=c, & a x^{2}+c=b x \\
b x=c, & b x+c=a x^{2} \text { șeklindedir (Corry 2017: 129). }
\end{array}
$$

Harizmi, problemleri sayılar da dâhil olmak üzere tamamen sözel bir biçimde ifade etmiștir. Örneğin birinci denklemi $\left(\mathrm{ax}^{2}=\mathrm{bx}\right)$, kareler katsayıya eșittir șeklinde ifade eder. Denklemleri formüle etmemesi, çözümü etkilemez. Çözüm için her hangi bir formülasyon ya da sembolik tanıma gitmeyerek bir "algoritma” önerir. Örneğin, bir sayının karesi ve on katının toplamı otuz dokuz olan sayının bulunması problemini, Harizmi șu şekilde çözer. Denklemi günümüz notasyonuyla; $x^{2}+$ Iox $-39=0$ șeklinde gösterebiliriz. Öncelikle sayının (x’in) katsayısını ikiye böleriz ve beși elde ederiz. Onu yani beși kendisiyle çarparız ve yirmi beși buluruz. Otuz dokuza yirmi beș ekleriz altmıs, dört olur ve bunun kare kökünü alarak sekizi buluruz. Sekizden de katsayının yarısı olan beși çıkararak sonucu üç olarak elde ederiz. Aradığımız sayı üçtür.(Corry 20I7: 130).

Harizmi'nin altı tip denkleminin sonuçları açısından ortak noktaları,

\footnotetext{
Elbette Harizmi'nin eserinden önce yazılmıș birçok cebirsel denklemi içeren kitap mevcuttu. Fakat Harizmi'nin eseri Diophantus'un Arithmetica'sının yanında bașlangıç düzeyi olarak görülse de, problem çözümlerinde cebir ve algoritma tekniklerini sistematik bir biçimde ustaca kullanmasıyla öne çıkar (Bkz. Boyer 2015: 260).
} 
hepsinin pozitif tam sayılar olmasıdır. Harizmi'nin denklemlerinde sayinın katsayısı ( $x$ 'in) konumunda negatiflik durumu söz konusuyken, sayının kendisinde negatiflik durumu yoktur. Bunun ana nedeni, sayının Antik Yunanlılarda olduğu gibi her hangi bir geometrik büyüklükle özdeșleștirilmesidir. Nitekim Harizmi verdiği sözel algoritma çözümlerinin ardından problemin geometrik çözümlerini de vermeyi ihmal etmemiştir. Harizmi yönteminin geçerliliğini şekillerin geometrik özellikleriyle temellendirmiş, böylece kesinliğin güvenli kaynağı olarak görülen geometri sayesinde çözümünü garanti altına almıștır.

Harizmi eserinde cebirsel yöntemlere dalmamıș, ișin özünde aritmetik ve sayıları kullanmayı tercih etmiștir. Harizmi'nin İslâm matematiğine ve akabinde Batı matematiğine cebirden sonraki en büyük katkısı, Hint rakamlarını tanıtmasıdır. I'den bașlayarak 9'a kadar olan bu rakamlar ve o sayesinde konumlu bir sayı sistemine sahip olan İslâm matematiği için bu hadise adeta aritmetikte bir devrimdir. Pythagorasçılar gibi Harizmi için tüm sayıları üreten sayı bir'dir. Bir tüm sayıları ürettiği için de diğerlerinden farklıdır ve sayı olarak kabul edilmez. Bir olmadan iki ve üç var olamaz, fakat iki ve üç olmadan da bir vardır (Corry 2017: 142). Harizmi eserini oluștururken her ne kadar Hint sayılarını kullanmıș ve Mezopotamya cebrinden esinlenmiș olsa da, sayılara olan bakıș açısında Aristoteles'in (M.Ö. 384-322) etkisi göze çarpmaktadır (Aristoteles 20I7: 480). Bunun nedeni muhtemelen İslâm filozoflarının Aristoteles'e olan hayranlıkları ve O'nu bütünüyle taklit etme çabalarıdır.

Konumlu sayı sistemi ve cebirsel yöntemlerin yanı sıra Harizmi'nin sayı konusundaki en büyük katkısı irrasyonel sayılar konusundadır. Pythagorasçıların irrasyonel sayıların farkına varmaları ve onları geometrik büyüklükler olarak göstermeleri șüphesiz büyük bir iști. Fakat bu sayede aritmetik, geometrinin bir parçası konumunda ilerlemek zorunda kalmıștı. Harezmi ise irrasyonel sayılarında aynen rasyonel sayılarda olduğu gibi aritmetik kuralların geçerli olduğunu gösterdi. Bunun neticesinde aritmetik tekrar bağımsız statüsüne kavușmuș oldu (Tahiri 20ı6: 26).

\section{Ortaçağ İslâm Dünyasında Sayı ve Nicelik}

İslâm filozofları Yunanlılardan aldıkları felsefe mirasında Pythagoras (M.Ö. 570 - 495) ve Yeni Platoncular'in ve en çokta Aristoteles'in tesiri 
altında kaldılar. Ortaçağ İslâm dünyasında felsefenin mahiyeti dört bölümden oluşuyordu. Bunlardan birincisi matematik, ikincisi mantık, üçüncüsü doğa bilimleri ve dördüncüsü de ilâhiyat bilimleridir. Felsefi bilimlerin ilki olarak görülen matematiği de dört alana ayırıorlardı. Bunlar; aritmetik, geometri, astronomi (ilm-i hey'et) ve müziktir (İhvan-1 Safa 2017: 33). Burada bahsi geçen bilimlerden astronomi Ptolemy'nin (M.S. ıOo- I60) Almagest'inin tasvir ettiği çerçevede düșünülmelidir. Müzik, seslerin bir araya getirilmesinin bilgisidir. Geometri, Euclides'in Elementler'inde aksiyomatik yapıda ve ispata dayanan bir bilimdir. Aritmetik ise özellikle Pythagoras ve Pythagoras'ın izâhına uygun olarak, varlıkların sayılara karșılık gelmesiyle elde edilen bilim olarak ele alınır.

Pythagorasçılar Müslüman düșünürler tarafından süratle İslâmileștirildi. İnsan çokluk âleminden sayı dizileri vasıtasıyla bir'e yükselebilir ve bir sayısı tevhid anlayıșına uygun olarak Allah'ı temsil eder (Nasr 2006: 75). Pythagorasçılar'ın İslâmileștirilmesi konusunda en çok çalıșmayı yapan topluluk İhvan-ı Safa'dır. X. yüzyılda Basra çevresinde yașayan bir felsefe topluluğu olan İhvan-1 Safa'nın risalelerinde bunun yansımaları net bir șekilde görülmektedir. “..sayıların ikiden önce "bir”den var olması ve olușması tasavvur edildiğinde "bir" bulunduğu durumla ilgili bir değișime uğramaz ve bölünmez. Ayn șekilde her ne kadar Aziz ve Celil olan Allab da seyleri vabdaniyet (birlik) nurundan yaratıp, ...” (İhvan-1 Safa 2017: 36-37).

Görüldüğü üzere İhvan-1 Safa'nın birinci risalesinin ilk kısmında geçen bu ifadeler, Pythagorasçı sayı anlayıșına İslâmi bir duruș kazandırıldığını açıkça göstermektedir. İhvân'dan önceki dönemde belirsiz yorumlarla ele alınan Pythagorasçı anlayıș, İhvân'la beraber İslâm'ın varlık anlayıșının bir parçası haline gelmiștir.

\section{2. İhvan-1 Safa'nın Aritmetik Felsefesi}

İsimlerinin anlamı 'gönlü arınmıș kardeșler' olan İhvan-1 Safa topluluğu, yașayıș ve örgütlenme açısından da Pythagorasçılar gibi davranmıșlardır (Cevizci 2008: I68). Temel ve en çok bilinen eserleri, toplam elli iki risaleden oluşan Resâilü İhvani’s Safa adlı içinde pek çok konuyu barınd1ran ansiklopedileridir (Uysal 2000: I). Bu risaleler sirasiyla matematik, fizik, psikoloji ve ilahiyat konularında olmak üzere dört bölümden olușur. On dört risaleden müteșekkil matematik bölümün ilk risalesi sayılar üze- 
rinedir. Pratik felsefe anlayıșını benimseyen İhvan, Pythagorasçı ve Sokratik felsefe tasarımı geleneğine tabiidir. İhvan'a göre felsefe hakikatin ne olduğu üzerine yapılan düșünsel bir faaliyet değildir. İhvan tarafindan felsefe, ölüme bir hazırlık, insanın gücü yettiğince Tanrı'ya benzemesi șeklinde tarif edilir (Cevizci 2008: I70). Bu tarife göre gerekli ahlâkî donanıma sahip olmadan felsefe yapmanın bir faydası yoktur.

İhvan, Pythagorasçılar gibi bilgiyle arınma arasında bir bağ kurar. Felsefe sadece teorik bir bilgi değildir ve insanı zihin, kalp, ahlâk ve fiiliyat alanında düzenleyen çevreleyici bir yașam biçimidir (Cevizci 2008: I70). İște böyle bir bilgi sayesinde insan günahlardan kaçınabilir ve hayatını erdemli bir șeklide arınmış olarak geçirebilir. Felsefenin ilk adımını matematiğin ve özelde sayıların olușturması derin bir kavrayıșa açılan kapının anahtarı mesabesindedir. İhvan'a göre sayı ilmi, diğer matematik ilimlerinin önüne alınmalıdır. Zira sayı bilgisi her nefisin içinde potansiyel olarak bulunmaktadır. Nefis, zaten kendisinde bulunan bu potansiyel sayesinde düșünebilmek için bașka ilimlere ihtiyaç duymaz. İhvan'a göre eğer insan, içindeki bu kabiliyetle sayllar ilmini dikkatlice incelerse, sayiların araz olduğunu ve varlıklarını sürdürmek için insan nefsine gereksinimlerinin olduğunu kavrar (İhvan-1 Safa 2017: 49).

İhvan'a göre kâinatın temelinde büyük bir düzen vardır ve bu düzeni sağlayan bir yaratıcı, Allah olmalıdır. Allah bu düzeni belirli bir ölçüde yaratmıștır ve Allah'ın ilmini elde etmenin yolu bu sayısal ilkeleri teșkil eden matematik ilmini ve özellikle de sayılar ilmini bilmekten geçer. Bu yaklaşımının temelinde, varlığın doğasının sayıların özelliklerine uygun olarak yaratıldı̆̆ı düșüncesi bulunur. Kâinat baștan sona bir düzen içerisinde yaratılmıștır ve bu yaratılıșin arkasındaki hikmeti ancak matematiksel bir açıklama ile bilebiliriz. Allah'ın kâinatın yaratılıșının ve tasarımının ardındaki tek varlık olduğunu, geliștirdikleri tasarım delili ile açıklamaya çalıșmışlardır. Tasarım delilini kullanmak için öncelikle yaratıcının yaratılan her șeyi belli bir dengede ve ölçüde yarattığını açıkça gösterecek bir yönteme ihtiyaç vardır (Koçhan ve Kılıç 20I7: 8I). İhvan'a göre bunu açıklamanın en iyi ve güvenilir yolu matematiksel ilkeleri kullanmaktır.

\section{I. İhvan-1 Safa'da Sayı ve Nicelik}

İhvan'a göre nicelik iki çeșittir: sayı ve sayılan. Sayı; nesnelerin formlarının büyüklügü, sayılan ise nesnelerin kendisidir. Hesap, sayıların top- 
lanması ve çıkarılmasıdır. Sayılar sahih denilen pozitif tam sayı ve kesirli (kusûr) sayılar olarak ikiye ayrılır. İhvan-ı Safa da aynı Pythagorasçılar gibi "bir"i sayı olarak kabul etmez. Bir sayıların bașlangıcı, kaynağı ve üreticisidir. Bütün sayılar ister kesirli sayı olsun ister tam sayı, bir'den doğar ve yine ona dönerler (İhvan-1 Safa 20I7: 34). Bir'den bir șey eksilemez çünkü onun parçası yoktur. Bire bașka bir eklendiğinde iki olușur, bu ikisine bașka bir eklendiğinde üç olușur ve bu durum böyle devam eder. Böylece bir, bütün sayıları olușturabilir.

İhvan, tüm sayıların aslının birden dörde kadar olduğunu yani I, 2, 3, 4'ten ibaret olduğunu söyler. Bunu söylemekteki maksadını ise şöyle açıklar. İhvan'a göre diğer bütün sayılar bu dört sayıdan olușur. Dördü bir ile toplarsak beși, dördü iki ile toplarsak altıyı, dördü üç ile toplarsak yediyi, dördü bir ve üç ile toplarsak sekizi, dördü iki ve üç ile toplarsak dokuzu, dördü bir, iki, ve üç ile toplarsak onu elde ederiz. Onlar, yüzler, binler vs. șeklinde devam ederek bütün sayılar olușturulmuș olur (İhvan-1 Safa 20I7: 36). Yine aynı șekilde İhvan'a göre geometride de bu ilke geçerlidir. İhvan "bir"e olan vurgusunu devam ettirir ve "Șanı Yüce Bârînin varlıklara nisbetinin "bir" in sayılara nispeti gibi" (İhvan-1 Safa 2017: 37) olduğunu ifade eder.

Sıfır sayısı ise İhvan'ın sayıları arasında yer bulamamıștır. Daha önce ilk kez sıfırı içi boș bir yuvarlak sembolüyle gösteren Harizmi'de olduğu gibi. İhvan risalesinin sayılarla ilgili kısmının devamında aynen Pythagorasçılar gibi her bir sayıya ait özellikler atfeder.

Örneğin bir, sayıların kaynağıdır.

İki, mutlak anlamda sayıların ilkidir.

Üç, tek sayıların ilkidir.

Dört, ikinin karesi alınarak elde edildiği için kare sayıların ilkidir.

Beș, devreden sayıların ilkidir yani, beș ile beșin çarpımının son hanesi yine beștir ( $5 \times 5=25$ gibi). Fakat sadece son hanede beș olması değildir mesele. 5 ile 25 çarpılırsa 5x25 = I25 eder. Yani onlar basamağındaki 2 de çarpımın sonucu olan sayıda yerini alır.

Altı, devreden sayılardandır, fakat beș gibi değildir. $6 \times 6=36$ eder, lakin $6 \times 36=216$ eder. Yani 3 çarpımın sonucunda onlar basamağına tașınmaz. Altı sayısını izah ederken İhvan mükemmel sayı tanımını verir; herhangi bir sayının kendisini bölen sayıların toplamı, kendisine eșit oluyorsa 
buna mükemmel sayı denir. Dolayısıyla altı mükemmel sayıların ilkidir.

Yedi, olgun sayıların ilkidir ve tüm sayıların anlamlarını içinde barındırır. Yedi, teklerin ilki olan üç ve çiftlerin ikincisi olan dörtten oluşur. Sayıların aslı olan bir ile mükemmel sayı olan altının toplamından yedi meydana gelir. Aynı zamanda gezegenlerin sayısı olan 7; 3+4, 2+5, I+6'nın toplamlarına eșit olmasıyla da ilginçtir. Çünkü bu sayıların her biri küp șeklindeki bir zarda karș1lıklı olarak bulunurlar (Schimmel 2018: 25).

Sekiz, ikinin küpü alınarak elde edildiğinden küp sayıların ilkidir. Sekizin üç boyutlu sayı olduğu da söylenir.

Dokuz, ilk kare tek ve aynı zamanda göklerin sayısıdır.

On, tıpkı birin birler basamağının ilk sayısı olması gibi o da onlar basamağının ilk sayısıdır.

On bir, (günümüzden farklı olarak) İhvan'a göre asal sayıların ilkidir. Yani birden bașka herhangi bir böleni yoktur.

On iki, artık sayıların ilkidir. Burada artık sayı derken bölenlerinin toplamı kendisinden büyük olan sayı kastedilmektedir. On ikinin bölenleri: $2+3+4+6=15$ olur ve I2'den büyüktür. Sonuç olarak her pozitif tamsayının kendini diğer sayılardan ayırt edecek farklı özellikleri bulunur (İhvan-1 Safa 2017: 38-40). İhvan'ın sayılara yaklaşımı, her șeyin arkhesinin karş̧ılı̆ının, maddi bir varlık olmayan 'sayı' olduğunu ileri süren Pythagorasçı öğretiyle neredeyse bire bir uygunluk gösterir.

\section{2. İhvan-1 Safa'nın Sürekli ve Süreksiz Nicelik Ayrımı}

İhvan, risalelerinin birinci cildinin on birinci kısmında, kategoriler bahsinde niceliği iki türe ayırır. Birincisi sürekli (muttasıl) ve ikincisi süreksiz (munfasil) niceliktir (İhvan-1 Safa 2017: 284). Sürekli nicelik geometrik nesnelerdir. İhvan'a göre geometri, miktarlar, boyutlar ve bu miktarların sahip oldukları özelliklerin bilgisinden ibarettir (İhvan-1 Safa 20ı7: 53). Sürekli nicelik beș çeșittir: çizgi, yüzey, cisim, mekân ve zaman. Bunlar da kendi aralarında gruplara ayrılır. Örneğin çizgi üç türlüdür: doğrusal, döngüsel ve eğimli. Yüzey de üç çeșittir: yalın (bâsit), kubbeli (dıș bükey), bâsık (iç bükey) (İhvan-1 Safa 2OI7: 284). Cisimlerin sınırları yüzeyler, yüzeylerin sınırları çizgiler ve çizgilerin sınırları da noktadır. Bu durumda her cisim bir yüzeyde bașlayıp bașka bir yüzeyde veya yüzeylerde biter. Yine aynı șekilde her yüzey bir çizgide bașlar, bașka bir çizgi veya 
çizgilerde biter. Ve son olarak her çizgi bir noktada bașlar ve bașka bir nokta veya noktalarda sona erer (İhvan-1 Safa 20I7: 65). Bu durumda cisimlerin sürekliliği garanti altına alınmıș olur. Aristotelesçi bir tarzla, İhvan'a göre fiziksel varlıklar arasında sürekli niceliklerde olduğu gibi herhangi bir boșluk bulunmamaktadır.

Süreksiz nicelik iki çeșitten meydana gelir; sayı ve hareket. Sayının da iki çeșidi vardır: tek sayı ve çift sayı. Sayılar başka bir bakış açısından yine iki grupta incelenebilir: tam olanlar ve kesirli olanlar. Yine farklı bir yaklașımla sayıları; birlere, onlara, yüzlere ve binlere ayırabiliriz. Hareket ise altı çeșitten oluşur: oluș, bozuluș, artma, azalma, bașkalașma ve yer değiștirme. Niceliğin özelliği ise İhvan'a göre eșitlik ve eșitsizliktir (İhvan-1 Safa 20I7: 284). İhvan'a göre aritmetikte sayılar için yapılan bu ayrımlar zorunlu ve gerekli değildir. Lâkin diğer filozoflar gibi İhvan da sayıları keyfi gruplara ayırmaktan kendini alamaz (Koçhan ve Kılıç 20I7: 86).

İhvan-1 Safa'nın sayı ve nicelik konusuna olan yaklașımı hakkında bir çerçeve çizdikten sonra, İslâm felsefesinin en büyük filozoflarından biri olan İbn Sina'nın (980-IO37) bu konudaki düșüncelerini kısaca ele alalım.

\section{3. İbn Sina'da Sayı ve Nicelik Kavramı}

Felsefe, matematik, tıp vs. gibi birçok alanda otorite kabul edilen İbn Sina'nın nicelik konusunda söyledikleri elbette incelenmeye değerdir. Özellikle Aristoteles'in İslâm felsefesinde en önemli ve etkili temsilcisi olan İbn Sina'nın nicelik konusunu detaylı olarak ele aldığı iki eseri bulunmaktadır. Bunlardan birincisi temel mantık konularını içeren Kategoriler ve diğeri ise mantık, metafizik ve fizik konuları hakkında yazdığ Dânișnâme-i Alầ adlı eserdir. Bunların yanında Fizik ve Metafizik adlı eserlerinde de sayı ve nicelik konularından bahseder. İbn Sina kendinden öncekilerden farklı olarak matematiği, doğa felsefesinin dıșında tutar. Bu sayede matematik kendi kulvarında gelișimini sürdürme imkânı bulur (Tahiri 20ı6: 26). İbn Sina'ya göre Antik Yunanlıların sayı konusunda iki farklı yaklașımından bahsedebiliriz. Bunlardan birincisi Platon'un sayıların ayrı varlıklara sahip oldukları iddiasıdır. İkinci yaklașım ise yine içerisinde iki gruba ayrılır. Birincisini temsil edenler Pythagorasçı görüștür ve nesnelerin sayılar tarafından teșkil edildiğini söyler. Diğer taraftan Aristoteles düşüncesinde sayılar potansiyel olarak vardır (Tahiri 20ı6: 27). 


\section{I. İbn Sina'nın Niceliğe Varlık Felsefesi Bağlamında Yaklaşımı}

Yüksek ilmin konusu tikel șeyler değil mutlak olması nedeniyle mutlak varlıklardır diyen (İbn Sina 20I3: 138) İbn Sina, varlığı kușatan on șeyin yüksek cinsler olduğunu belirtir. Varlık ise iki gruptan oluşur; cevher ve arazlar. Bu on șeyden birisi cevher, diğerleri yani dokuzu arazdır. İbn Sina Kategoriler'de arazı tanımlarken "araz ya dışarıdan başkası sebebiyle üzerine vârid olmadı̆̆ konusunda karar kılmıs ve söz konusu dıșarıdakine bir nispete ibtiyaç duymaz" (İbn Sina 20I4a: III) ifadesini kullanır. Bu durumda araz olmayan ve varlığ bir konuda bulunmayana da cevher denir. Kategoriler olarak geçen bu on șey: cevher, nicelik, nitelik, görelilik, mekân, zaman, durum, iyelik, etki, edilgiden olușur. Bu kategorilerin cevher dıșındaki dokuzu tek bașlarına ne doğru ne de yanlıștırlar. Yani tek bașlarına bir șeyi doğrulayamaz ya da reddedemezler. Ancak birbiriyle bağlantı içerisinde olduklarında tanımlamalarda anlamlı hale gelebilirler.

Nicelik, kategorilerde cevherden hemen sonra gelir. Bunun nedeni cevher ve nicelik arasında ortaya çıkan ortak özelliklerdir. Bu özellikler için görelilik ve niteliğe ihtiyaç bulunmamaktadır. İbn Sina'ya göre niceliğin daha önce gelmesinin sebebi, niceliğin varlık açısından nitelikten daha genel ve görelilikten daha gerçek olmasıdır. Nicelik nitelikten daha geneldir, çünkü sayı niceliktir. Dolayısıyla sayının varlığında madde ve hareketle sınırlı olmaması bunu sağlamaya kâfidir. Diğer taraftan nicelik, görelilikten daha gerçektir. Görelilik bulunduğu șeyde nicelik gibi karar kılmıș değildir. Bitișik olan nicelik cisimlerde değișme olmaksızın bulunurken, nitelikler cisimlerde değișime uğrar (İbn Sina 20I4a: I45).

İbn Sina bu noktada niceliğin cevher mi yoksa araz $\mathrm{m} 1$ olduğunun sorgulanması gerektiğinin altını çizer. Eğer niceliği maddi cismin bir özelliği olarak tanımlarsak, yani nicelik cismi, cisim olarak kuruyor ise nicelik cevher olur (İbn Sina 20I4a: I46). Çünkü ancak cevherler kurucu surettedir. Peki İbn Sina'ya göre cismin tanımı nedir?

\subsection{Cismin İzâhı}

İbn Sina Dânişnâme-i Alầ adlı eserinde; kesintisiz, sınırlı ve üç boyutu ölçülebilen her șeyin cisim olarak kabul edilebileceğini söyler (Karlıăga 1993: 29). Cisim madde ve suretten olușur. Cismin bulunduğu üç boyut; birinci boyuta boy, ikinci boyuta en ve üçüncü boyuta derinlik denir. 
Cisim bu üç boyut olmadan, mevcut olamaz. Lakin bahsettiği bu üç boyutun sadece vehmi çizgilerden ibaret olduğunu da belirtmeden geçmez (İbn Sina 20I3: I44). Cisim kendisinde üç boyutu kabul etmesi açısından, yani ölçülebilir olmasından dolayı cisimdir. Bașka bir deyișle bu ölçme ister cismi kararlı kılsın ister kılmasın cisim olması ölçülebilir, olmasından dolayıdır (İbn Sina 2014a: 147).

Cisimler suret olarak farklı değillerdir yani hepsi üç boyutludur. Cisimler boy, en ve derinlik bakımından farklı olsalar da farazi olarak birdirler (İbn Sina 20I3: I48). Buradan hareketle İbn Sina cismi izah ederken cismin parçalanmaz atomlardan oluștuğu fikrini eleștirir ve cismin ancak kesintisiz ya da sürekli olması gerektiğini söyler. Cisim parçalardan (atomlardan) mürekkep değildir, eğer cismin kurucusu parça (atom) olsaydı cisim sınırsız ve ölçülemez olurdu (İbn Sina 20I3: 156). İbn Sina bu noktada kanıt olarak aynen Zenon'un hareket ile ilgili paradokslarında verdiği örneklere benzer bir örneğe bașvurur. Bir kimse bir yerde olmak isterse önce gideceği yolun ortasına, sonra ortanın ortasına ve daha sonra ortanın ortasına varması gerekir. Bunun sonucu Zenon'un paradoksundaki pirenin bașına gelenle aynıdır. ${ }^{2}$ Asla gitmek istediği yere ulașamaz. Öyleyse cismin maddesi suretin tamamını kapsadığı yani, kesintisiz (sürekli) olduğunda kabul edilebilir (İbn Sina 2013: 158).

\subsection{Nicelik Türleri}

\subsection{Sürekli Nicelik}

Nicelik aynen İhvan-1 Safa'da olduğu gibi sürekli ve süreksiz nicelik olarak ikiye ayrılır. Fakat İbn Sina niceliği metafiziğin içinde incelediği için kastettiği sürekli ve süreksiz nicelik, İhvan'ın tanımlarından farklılık gösterir. İbn Sina'ya göre bitișik, yani sürekli nicelik parçalarının konumu olan, ayrıșık yani süreksiz nicelik parçalarının konumu olmayandır (İbn Sina 20I4a: I49). Sürekli nicelik kendi arasında dörde ayrılır:

2 Zenon'un bölünme paradoksudur. Verilen iki birim mesafeyi zıplaması istenilen bir pireden tek bir kurala uyması beklenir. Verilen mesafenin önce yarısını, sonra yarısını gitmeden önce dörtte birini, daha sonra dörtte birini gitmeden önce sekizde birini, vs. gitmesi istenir. Varsayalım verilen mesafe 2 metre olsun. Pire kurala uyarak önce I metre ziplasın. Daha sonra yine kural gereği kalan mesafenin yarısı yani $\frac{1}{2}$ metre zıplasın. Daha sonra $1 / 4$, daha sonra I/8 ...vs. șeklinde sonsuz sayıda zıplasın, fakat sonlu mesafe tükenmemektedir. Böylece sonsuz sayıda noktayı sonlu sayıda bir zaman içerisinde geçmesi imkânsız olur. Oysaki verilen mesafe sonluydu, sadece 2 metre. Zenon'un bu paradoksla saçma bir duruma indirgediği olay, aslında her türlü hareketin imkânsız olduğuydu (Bkz. Nesin 2010: 50). 
I. Birincisi uzunluk (doğru) șeklindeki niceliktir ve onda cisim ancak düșünce durumundadır. Bilfiil olduğunda çizgi olarak adlandırılır.

2. İkincisi genișlik ve uzunluktan olușan niceliktir. Bilfiil olduğunda yüzey olarak adlandırılır.

3. Üçüncüsü derinlik, genișlik ve uzunluktan olușan niceliktir. Bilfiil olduğunda cisim olarak adlandırılır.

4. Dördüncüsü ise zamandır. Çünkü zaman hareketin ölçüsüdür (İbn Sina 2013: I68).

Bu dört sürekli nicelik incelendiğinde İbn Sina'ya göre niceliğin araz olduğu, yani kendi bașına bir varlığa sahip olmadı̆̆ı ve var olmak için bașka bir tașıyıcıya gereksinimi olduğu sonucu çıkarılır. Örneğin kesișen iki doğru bir nokta, kesișen iki yüzey bir doğru ve kesișen iki cisim bir yüzey ve zamanın iki parçası arasında da "an” yani șimdi meydana gelir (İbn Sina 20I3: I70). Bütün bunlar kendi bașlarına olușamazlar, böylece sürekli nicelik kurucu olmadığından cevher olarak değil araz olarak nitelenir.

Cisimlerin ölçülmesi nicelik ile mümkün olmuștur. Kategoriler kullanılarak cismi tanımlarsak, cismin sureti niceliği ile birlikte soyutlandığı durumda, matematiksel cisim elde edilmiș olur (İbn Sina 20I4a:I49). Cismin sürekli bir nicelik olduğunu söylemiștik. Cismin parçalarının arasında ortak olan sınır yüzeydir. Benzer șekilde yüzeyin parçalarının arasındaki ortak sınır çizgi iken, çizgi için nokta aynı şartı sağlamaz. Bu durum, zaman için de böyledir. Çünkü zaman da geçmiş ve gelecek arasında bitișik (sürekli) olan “an”'ı süreksiz izole bir nokta olarak göremeyiz (İbn Sina 20I4a: I5I). Öyleyse duyularımızla algıladı̆̆ımız cisim, ancak boyutları bakımından parçalara ayrılabilir.

\subsubsection{Süreksiz Nicelik: Sayı}

İbn Sina'ya göre tek süreksiz nicelik sayıdır. Süreksiz niceliğin parçaları birbirinden ayrı meydana geldiği için ortak bir sınırı bulunmaz. Örneğin I3 sayısının parçaları olan 8 ve 5 sayılarının arasında ortak bir sınır bulamayız. 8 parçasıyla 5 parçasının arasında ortak bir "birlik" yoktur. Aslında İbn Sina'nın burada bahsettiği mesele, modern küme teorisinde kesișen kümelerin durumuyla izah edilebilir. Yani 8 sayısı ile 5 sayısı arasinda ortak bir birlik bulunsaydı, I3 sayısı ortak olan birlikten dolayı I eksilip I2 olacaktı. Böylece sayıların arasında ortak bir sınır olmadı̆̆ı anlașılarak, sürekli olamayacakları gösterilmiș olur. 
Süreksiz nicelik olma șartı olarak İbn Sina'nın verdiği ölçüt; herhangi bir șeyde ölçme ve eșit olup olmamanın belirli kılınmasıdır(İbn Sina 20I4a: I57). İbn Sina'ya göre süreksiz nicelik olan sayının kurulușu, ayrık șeylerden, bașka bir ifadeyle birliklerden olușur. Sayının birliklerden olușması, sayının da nicelik gibi araz olduğunu gösterir. Sayıların parçalarının yani birliklerinin bir düzeni ve kararı olsa da, sayı için süreklilik yoktur (İbn Sina 20I4a: I66). Gerçekte sayı bir konum gerektirmez. Sayı ancak birlikte olduğu șey vasitasıyla konum sahibi olur. Konum sahibi olan nicelik ölçüdür ve gerçek ölçüler cismi içine alan üç boyuttur. Mekânla beraber dört olur. Zaman, sayı ve söz konum sahibi değillerdir.

İbn Sina’ya göre süreksiz olan sayı, aynı zamanda sınırlıdır.

$\mathrm{Fi}$ ziksel dünyada sonsuz sıralama sahibi olan tüm sayılanların sonsuza doğru gidiși ya sayı doğrusu gibi tek bir yönde ya da yüzey gibi tüm yönlerde olur. Eğer tüm yönlerde olursa sayı gurubundaki 'bir' sayısı gibi bir sınır varsaymak durumunda kalırız. Örneğin sonsuz $B$ yönünde $A B$ doğrusundan AC gibi sınırlı bir doğru parçası alınsın. Onun üzerinde (parçası alınmıs, olanın) $\mathrm{AB}$ alınırsa kaçınılmaz olarak $\mathrm{AB}$, ya $\mathrm{CB}$ doğrusuna eșit olacak ya da aralarındaki bağıntı her ikisinin de sonsuza kadar $\mathrm{AB}$ doğrultusunda veya $A B$ 'den $A C$ doğru parçası uzunluğunda eksik olarak gideceği șekilde olur. Diğer bir olasılıkla, eğer AB doğrusu, CB doğrusuna sonsuza kadar çakıșık olsun. CB doğrusu, AB doğrusunda bir parça olarak bulunsa, bu durumda bütün doğru ve aynı zamanda bir doğru parçası çakıșık olurlar ki, bu çelișkidir. Eğer $\mathrm{CB}$ doğrusu, $\mathrm{AB}$ doğrusundan $\mathrm{B}$ yönünde kısa kalır ve ondan eksik olursa, bu durumda CB doğrusu sonlu olur. Dolayısıyla AB'de sonlu olmuș olur, hâlbuki sonsuz sayılmıștı. Sonuç olarak ölçüler ve sıralı sayılarda bilfiil sonsuzluğun varlığı olanaksızdır (İbn Sina 2005: 49-50).

\subsection{Sayının Mahiyetinin Belirlenmesi}

Sayılar İbn Sina'ya göre hem fiziksel hem de zihinsel olarak mevcuttur (İbn Sina 20I4b: IO6). Dolayısıyla sayının sadece zihinde bulunduğu iddiası asılsızdır. Aslında İbn Sina burada matematiksel nesnelerin ontolojisi açısından Platon'un görüșünü eleștirir. Platon'a göre matematiksel nesneler ideal varlıklardır ki bu durumda zihinsel olan mantıksal olandan kopartılmıs, olur. İbn Sina'ya göre matematiksel nesnelerin varlığını Platoncu düşüncenin ispatlaması gerekir (Tahiri 20ı6: 28). İbn Sina’ya göre sayı fiziksel varlıklardan ayrı düşünülerek, matematiksel ișlemler açısından 
ele alınmalıdır. Daha önce de izah edildiği üzere bir'in dıșındaki her bir sayı ayrı bir türü meydana getirir ve tektir. Sadece bir tane 8 vardır. Ve her bir türün ayrı özellikleri bulunur. Sayıların her birinin ayrı bir hakikati ve zihinde ondan tasavvur edilen bir sureti mevcuttur (İbn Sina 2OI4b:IO7).

Aynı minvalde sayıların birliklerden olușumunu on sayısını örnek vererek izah eder. On sayısı; iki ile sekizden, üç ile yediden, dört ile altıdan ve beș ile beșten müteșekkil olabilir. Bu sayılan ikili gruplardan her biri on sayısını olușturmaya yeterlidir ve bu sebepten sadece biri onu ifade etmek için kâfi iken, diğerlerine ihtiyaç bulunmamaktadır. Bu ikililerin ortak özellikleri toplamlarının on olmasıdır. Ayrı ayrı ele aldığımızda bu sayıların kendilerine ait özelliklerinin on sayısı açısından bir önemi yoktur. Bu sayılar arasında on sayısının hakikatine yeterli gelecek ortak payda, birliklerdir (İbn Sina 20I4b: IO8).

Aslında her bir sayının hakikati, söz konusu sayının birliğinden ibarettir. Her bir sayı toplama özelliği sayesinde bașka sayılarda bulunmayan özelliklere sahip olur. Örneğin 6 sayısı 2 ve 3 tarafından bölünebilirken 7 sayısı böleni olmadığı için asaldır. Sayıların hakikati noktasında sayısal sayı görüșünü benimseyen İbn Sina'ya göre, her bir sayının bașka sayılardan farklı kendine özgü birlik ve hakikati bulunur (Demirci 2015: 35). Aristoteles gibi İbn Sina da bir'i sayı olarak kabul etmez. Ancak Aristoteles'ten farklı olarak iki de İbn Sina için sayı değildir. Çünkü iki, çiftlerin ilkidir ve sayı teklerden meydana geldiği için ilk gerçek sayı üçtür (İbn Sina 2014b: 109).

İbn Sina'ya göre say1; “bütün birleri zikreder, bir, bir, bir...vs. birleșmesinden oluşan șeydir" (İbn Sina 20I4b: IO8). ${ }^{3}$ Bunun manası sayının birlerle ölçülen süreksiz nicelik olarak tanımlanmıs, olması demektir. Sayı iki yönüyle bilinir. Birincisi sayının meydana geldiği terkibe değinilmeden saynın kendisiyle ya da özellikleriyle bilinmesidir ki, bu șekilde sayının resmi bilinmiș olur, cevheri değil (İbn Sina 20I4b: IO8). Örneğin yedi sayısı; üç ile dördün toplamıyla ya da asal olması özelliğiyle biliniyorsa bu onun sureti hakkında bir bilinmedir.

3 Aristoteles'in tanımında ise sayı İbn Sina ile benzer biçimde, 'birliklerden kurulu çokluk' olarak tarif edilir (Bknz, Aristoteles 2017: 1056 b (20-25)). 


\section{Sonuç}

Harizmi'de sayıların Aristoteles'ten farklı bir tanımının yapılmadığını ve yine birliklerden kurulu çokluk nazarından değerlendirildiğini görüyoruz. Bunun en iyi örneği sıfırın cebirsel ișlemlerde kullanıldı̆̆ı halde sayı olarak görülmemesidir. Dahası yine Aristoteles'in tanımının dışına çıkılamamıs, bir, üretici bir sayı olarak değerlendirilerek sayılar ikiden başlatılmıștır. İhvan-1 Safa topluluğu da sayı ve nicelik konusunda dönemin paradigmasının dıșına çıkamamıștır. Harizmi’den farklı olarak sayıları daha çok metafizik bir unsur olarak gören İhvan, onlara tıpkı Pythagorasçılar gibi her bir sayıya ait özellikler atfetmișlerdir. Örneğin bir Allah'ı temsil eder ve tevhid anlayıșına uygun olarak insan, çokluk âleminden sayı dizileri vasıtasıyla bir'e yükselebilir. İhvan için sayılar ve sayısal ilkeler hakkında bilgi sahibi olmak ruhsal arınmanın ilk aracıdır.

İhvan tarafından İslamileștirilen Pythagorasçı felsefe, İslâm'ın varlık anlayıșına dâhil olmuștur. İhvan'ın metinlerinde insanın aklıyla düșünebilmesi için matematikten başka ilme ihtiyacı olmadığı vurgusu, șüphesiz matematiğin gelip geçici bir bilgi olmadığı fikrini savunan Platon'un düşüncesinin açığa çıkmasıdır. İhvan niceliği, sürekli ve süreksiz nicelik olarak iki kısımda inceler. Sürekli nicelikler geometrik nesneler olan; çizgi, yüzey, cisim ve bunlara ilaveten zaman ve mekândır. Pythagorasçılarin nokta tarifi, konumu olan birimdir. Pythagoras sonrasında Zenon'un buna itirazı olmuș, hareket halindeki noktaları baz alarak, paradokslarıyla zaman ve mekânın bölünemez sürekli nicelik olduğunu göstermiștir. İhvan-1 Safa, zaman ve mekânı sürekli nicelikler arasına dâhil ederek hareketin sürekliliği probleminden kurtulmuștur. İbn Sina'da ise bu beșliden mekân, sürekli nicelikler arasında sayılmamıștır.

Süreksiz nicelikler İhvan-1 Safa'da sayı ve harekettir, İbn Sina'da ise sadece sayıdır. İhvan'a göre sayı; nesnelerin formlarının büyüklüğüdür. Yine bu noktada İhvan'a göre sayılar; Pythagorasçıların atomik sayıları değil, Euclides'in Elementler'inde tarif ettiği șekliyle doğru parçalarıdır. Yani sayılara yüklenen mistik anlamların yanı sıra fiziksel olarak sayılar, geometride doğru parçalarıyla karșılıklarını bulurlar.

İbn Sina, nicelik kavramını varlığı olușturan on cinsten biri olarak ele alır. Sürekli nicelikler olarak gördüğü çizgi, yüzey, cisim ve zaman ile 
âlemde bulunan fiziksel cisimlerin sürekliliğini garanti altına alır ve herhangi bir boşluk fikrini ortadan kaldırır. Böylece cismin parçalanmaz atomlardan oluştuğunu söyleyen atomculara karșı çıkar. Süreksiz niceliğe gelince, İbn Sina'ya göre tek süreksiz nicelik sayıdır. Sayıların ortak bir sınırları bulunmaz. Sayının kurulușu da ayrık olan birliklerden meydana gelir. Bu sebepten bir, gerçek bir sayı değildir. Ayrıca İbn Sina’ya göre iki de çift sayıların ilkidir ve o da gerçek bir sayı sayılmaz. Yani sayıları üçten bașlatır ve bu konuda Aristoteles'ten ayrılır.

İhvan'ın sayı ve nicelik konusunda Pythagorasçı öğretinin etkisi altında olduğunu kabul etmekle beraber sayıların atomik noktalar halinde değil de Euclides’in anlayıșına uygun olarak bir doğru üzerinde sıralanan noktalar olarak kabul ettiklerini görüyoruz. İbn Sina'nın ise daha çok Aristoteles'in fikirlerinin etkisi altında kaldığı söylenebilir. Bunun yanında İbn Sina'nın matematiksel nesnelerin ontolojisi konusunda ne Platon ne de Aristoteles'le aynı düșünmediği ortadadır. İbn Sina matematiksel nesnelerin varlığının Platon'un iddiasında olduğu gibi ne sadece idealardan ibaret olduğu, ne de Aristoteles gibi onların sadece tanım olarak var olabilecekleri ve gerçekte var olamayacakları düșüncelerini reddeder.

\section{Kaynaklar}

Aristoteles (20I7). Metafizik. (Çev. A. Arslan). İstanbul: Divan Kitap Yayınları.

Boyer, C. B. (2015). Matematiğin Taribi. (Çev. S. Bağcacı). İstanbul: Doruk Yayınları.

Cevizci, A. (2008). Ortaçă̆ Felsefesi Tarihi. Bursa: Asa Kitabevi.

Corry, L. (20I7). Sayıların Kısa Taribi. (Çev. Ö. Kesici). İstanbul: Doruk Yayınları.

Demirci, M. F. (2015). İbn Sina'da Nicelikler ve Sayı, AİBய̈ İlabiyat Fakültesi Dergisi, 6 (3).

İbn Sina (20I4b). Metafizik. (Çev. E. Demirli \& Ö. Türker). İstanbul: Litera Yayincilik.

İbn Sina (20I3). Dânişnâme-i Alâi. (Çev. M. Demirkol), İstanbul: Türkiye Yazma Eserler Kurumu Bașkanlı̆̆g.

İbn Sina (20I4a). Kategoriler. (Çev. M. Macit). İstanbul: Litera Yayıncılık.

İbn Sina (2005). Fizik II. (Çev. M. Macit \& F. Özpilavc1). İstanbul: Litera Yayınc1lik. 
İhvân-1 Safâ (20I7). İhvân-ı Safâ Risaleleri, c. I. (Çev. Komisyon). İstanbul: Ayrıntı Yayınları.

Karlığa, B. (1993) . Cisim. İslam Ansiklopedisi, c. 8. İstanbul: TDV Yayınları.

Koçhan, M. \& Kılıç, M. F. (20I7). Matematik İhvan-1 Safa Felsefesinin Dayandığı Aksiyomatik Zemin midir?.Artuklu Akademi Dergisi, 4 (2).

Nasr, S. H. (2006). Islam ve Bilim: İslam Medeniyetinde Pozitif Bilimlerin Taribi ve Esasları. (Çev. İ. Kutluer). İstanbul: İnsan Yayınları.

Nesin, A. (2OIO). Matematik ve Gerçek. İstanbul: Nesin Yayıncılık.

Schimmel, A. (20I8). Sayıların Gizemi. (Çev. M. Küpüșoğlu). İstanbul: Alfa Yayınları.

Tahiri, H. (2016). Mathematics and the Mind: An Introduction into Ibn Sina's Theory of Knowledge. Cham: Springer.

Uysal, E. (2000). İhvan-1 Safa. İslam Ansiklopedisi, c. 22. İstanbul: TDV Yayınları.

Öz: Sayı ve nicelik konusu binlerce yıldır tartıșılan ve hala tanımının tam olarak yapılamadığı matematik felsefesinin en temel konusudur. Bu makalede İslâm felsefesinde sürekli ve süreksiz niceliği Pythagorasçı ve Aristotelesçi olmak üzere iki farklı yaklaşımla ele alan İhvan-1 Safa topluluğu ve İbn Sina gibi iki büyük felsefe ekolünün düşünceleri incelenmeye çalıșılmıștır. Pythagorasçı öğretiden çok etkilenen İhvan-ı Safa, sayıları her șeyin temel ilkesi olarak kabul etmiş ve İhvan'la beraber Pythagorasçı anlayış İslâm'ın varlık anlayıșının bir parçası haline gelmiștir. Diğer taraftan Aristotelesçi geleneğe bağlı kalan İbn Sina, kategoriler ekseninde ve cinslerin bağımsızlığı ilkesi bağlamında sürekli ve süreksiz nicelik kavramlarını ele almıștır.

Anahtar Kelimeler: İhvan-1 Safa, İbn Sina, sayı, nicelik, matematik felsefesi, Aristoteles, Pythagoras. 